\title{
PECULIARITIES OF THE COMMUNICATIVE COMPETENCE DEVELOPMENT OF FUTURE AGRARIAN SPECIALISTS
}

Summary. The article deals with the problem connected with the language competence of future agrarian specialists. It has been studied that the professional competence provides students with the knowledge and skills to obtain information effectively and efficiently. It defines the structure of communicative competence and for realization of scientific researches in the process of educational activity. A set of exercises and tasks has been determined, and a number of problems regarding to the definition of hidden elements of communicative competence and the ways of their solution have been outlined. A comparative analysis of the interpretation of the general scientific term "competence" has been made and a new interpretation in accordance with the economic field of society has been introduced. The overview of recent research and publications has been showed that the communicative culture is an important part of the professional competence of future agrarian specialists. It enriches the knowledge of a specialist by adding the information about the peculiarities of professional communication. It should be noted the problem of the formation of professional competence of agrarian specialists in the conditions of modern higher education is one of the main in a number of current educational problems. The purpose of the article is to identify theoretical bases necessary for the acquisition of professional competence by a future agrarian specialist. Special attention is paid to the problematic method of teaching in foreign language classes. It has been determined that this method involves, activates the creativity of students and searches their potential, facilitates the development of skills for making their own right decisions and gives an opportunity to choose options and actions and, ultimately, it independently masters the foundations of the communicative competence. Keywords: problematic method, professional competence, competence, professional communicative competence, future specialist.

Манжос E.O.

Вінницький національний аграрний університет

\section{ОСОБЛИВОСТІ РОЗВИТКУ КОМУНІКАТИВНОЇ КОМПЕТЕНТНОСТІ МАЙБУТНЬОГО СПЕЦІАЛІСТА АГРАРНОЇ ГАЛУЗІ}

\begin{abstract}
Анотація. У статті розглянуто проблему, пов'язану з мовленневою компетенцією майбутніх фрахівців аграрної галузі. Було доведено, що професійна компетентність забезпечуе студентам знання та навички для отримання ефрективної та необхідної інформації і визначає структуру комунікативної компетенщії та використовується для здійснення наукових досліджень у процесі навчальної діяльності. Визначено комплекс вправ та завдань, окреслено низку проблем щодо визначення прихованих елементів комунікативної компетенції та шляхів їх вирішення. Здійснено порівняльний аналіз тлумачення загальнонаукового терміна "компетентність" та запроваджено нове тлумачення відповідно до економічного запиту суспільства. Огляд останніх досліджень та публікацій показав, що комунікативна культура є важливою частиною професійної компетентності майбутніх аграрних фрахівців. Розвиток комунікативної культури збагачуе знання фрахівця, додаючи інформацію про особливості професійного спілкування. Слід зазначити, що проблема формування професійної компетентності аграрних фахівців в умовах сучасної вищої освіти є однією з головних у низці актуальних освітніх проблем. Комунікативна діяльність майбутніх фахівців сільського господарства - це складний процес професійної культурної рефлексії у процесі діяльності, що потребує розширення підходів до профресійної компетентності у процесі навчання студентів. Розвиток комунікативної культури в процесі вивчення іноземних мов реалізуеться в практичній діяльності, що передбачає організацію методів навчання. Використання інтерактивних методів дозволяе учням засвоювати навчальний матеріал у формі активної роботи, не лише у формі запам'ятовування, вимагаючи застосування індивідуальних пізнавальних стратегій розвитку комунікативних навичок. Це стимулюе студентів не тільки краще засвоювати іноземну мову, але й сприяе розвитку навичок, необхідних у їхній майбутній професійній діяльності. Мета статті - виявити теоретичні основи, необхідні для набуття професійної компетентності майбутнім аграрним фахівцем. Особлива увага приділяеться проблемному методу викладання на заняттях з іноземної мови. Визначено, що цей метод передбачає, активізує творчість студентів та їхній потенціал, сприяє розвитку навичок прийняття власних правильних рішень та дає можливість вибору варіантів навчальної діяльності i, зрештою, дає можливість самостійно опановувати основи комунікативної компетентністі.
\end{abstract}

Ключові слова: проблемний метод, професійна компетентність, компетентність, професійна комунікативна компетентність, майбутній фахівець.

Droblem statement. The problem of formation of a future specialist professional competence is the integrative combination of qualities and skills, which contains such principal methods as the finding, obtaining, processing, presentation and the transmission of information. These methods also include the analysis, synthesis, comparison, gener- alization, systematization and the transformation of obtained information into knowledge. They are the most important qualities and skills of specialist competence. The professional competence provides students with the knowledge and skills to obtain information effectively and efficiently. At the same time, it helps students to analyze and select information 
from a variety of sources, especially from the Internet. Recently multimedia technologies affect the development of professional competence significantly. The problem of the development of professional communicative competence of agrarian specialists in the conditions of modern higher pedagogical education is one of the main in a number of current educational problems. The formation of the student professional thinking of theoretical, methodological and ideological culture [3, p. 330].

Thus, the purpose of the article is to implement more advanced concepts and technologies based on a high level and, of course, to use new approaches to solve educational problems at all levels of training, starting with the primary and finishing up the higher education [8, p. 4].

Recent research and publications. One of the basic requirements of the modern labor market to a specialist is, first of all, an appropriate level of a specialist professional competence: the ability to carry out professional activities effectively, to perform functional responsibilities more flexibly and mobile, and to understand the importance of goals and good results being achieved [5, p. 197].

First of all, the modernization of the current professional agrarian education in Ukraine is related to the implementation of a competence approach in the educational process, according to which the learning outcomes are evaluated on the basis of knowledge, abilities, skills and competencies.

The competence-based approach is widely introduced in modern pedagogical researches: V. Bidenko, N. Bibik, I. Bespalko, I. Sasun, N. Kuzmina, A. Markova, L. Mitina, A. Ovcharuk, L. Petrovskaya, L. Puhovski, A. Savchenko, G. Tereshchuk, A. Hamlet, V. Shapkina, etc. It is considered by scientists as a methodological approach. This approach focuses on the self determination and self realization of students.

Presentation of the main material. The current stage of social development is characterized by widespread use of computer equipment, new information technologies, telecommunications, new types of document communication, and the requirements for professional training of specialists, in particular to the level of their communication and information competence, are increasing. According to the globalization of various sectors of agriculture and the accession of Ukraine to the Bologna process, the organization of learning process in higher education requires some significant changes. In the system of vocational agricultural education and science of Ukraine, based on the program of action needed for the implementation of the Bologna Declaration is stated that the priority task is the establishment of an adequate system for a determining level of graduates ' professional competence of all Ukrainian agrarian universities. It is also necessary to develop the estimation methods of certain educational and qualified levels of specialists` competence in Ukraine.

Ukrainian scientists have determined that the most important task of modern education is its reorientation to the definition of competencies, which provide the quality of education more adequate to the requirements of the time.

In the explanatory dictionary of Ukrainian language the term "competence" (lat. Competentia) concerns a person "who has sufficient knowledge in a particular field, who is clever and intelligent" or "who has an absolute power and sovereignty" [1, p. 445]. According to the definition of the European Commission, the competence is a dynamic combination of knowledge, understanding, skills, values, and personal qualities that describe the learning outcomes of the curriculum [6].

The problem of the formation of professional competence is devoted to the scientific works of S. Cooper, V. Davydov, K. Korsak, A. Markova, J. Raven, V. Strelnikov, S. Tishchenko, L. Khoruzhaya, I. Yashchuk and others in which the basic issues on the structure and content of the concept of professional competence are discussed. The theoretical view relating to the professional competence is presented in the works of N. Balovsyak, I. Bassina, W. Bespalov, D. Merosina, S. Fedorova and others. Various aspects of professional competence of future specialists in Ukraine are covered by I. Goslavski (the notion of competence in domestic and foreign pedagogy); A. Noodles (the development of competence approach in the education of the European Union); A. Ovcharuk (new directions of educational innovation in Ukraine in the context of competence approach); O. Pometun (the competence-based approach which is the most important orientation in the development of modern education), etc.

We have come to the conclusion that the competence is an information awareness of issues that a person has a good knowledge of and that can be fully implemented in practice.

Professional competence is determined by the range of specific issues of any organization, institution or person in which it has specific authority and where a person will be able to apply their knowledge and experience. The analysis of these and other studies shows that the concept of professional competence and competency in psychological and pedagogical literature has an ambiguous interpretation.

Some researchers define professional competence as the willingness of a specialist to apply knowledge into practice, while others - the ability to solve problems. But most of them agree with the opinion that the term competence is closer in meaning to the understanding of "know how" than "know what". The same ambiguity can be traced in the interpretation of the notion of competency.

In our opinion, the terms competence and competency in the aspect of professional education are the most appropriate. We agree with the researchers who believe that professional competence is the main potential approach necessary for future professional activity of students. Therefore, the competency is an actual demonstration of the competence in the professional activity.

On the basis of the sources and of the various approaches we have concluded that the professional competence determines the level of professionalism, and the achievement of required skills and abilities. It constitutes the purpose of a professional activity of specialists.

The professional communicative activity is the main function of future activity of specialists. It deals with the informative exchange and cultural transfer of professional roles and work experience. The communicative competence helps to learn English not only receptively but also in the productive term. The productive term implies the willingness of using language units in the process of professional learning. The communicative competence ensures conditions 
for the development of language abilities. The communicative competence is an important part of the professional culture of a specialist. It enriches the knowledge of a specialist by adding the information about the peculiarities of professional communication.

Thus, communicative activity of future specialists of agriculture is a complex process of the professional cultural reflection in the process of activity, which requires the need to expand the professional competence approaches in the process of student training. The development of communicative culture in the process of learning foreign languages is realized in the practical activity that involves the organization of learning methods. The use of interactive methods allows students to learn the training material in the form of an active work, and not just in the form of memorization by requiring the application of individual cognitive strategies for the development of communicative skills. This stimulates students not only to learn better a foreign language, but it also promotes the development of skills, necessary in their future professional activity.

The rapid enlargement in the volume of educational material with the simultaneous trends to decreasing time to study it requires the intensification of the learning process. Learning to work is the ability to master the professional knowledge and skill to operate them, having different professional roles in the team work $[1 ; 4 ; 9]$. This requires the finding effective ways of organizing and operating the learning process and the searching for the reserves of improvement the educational quality.

In the teaching of the humanities, one of the learning technologies for the formation of communicative competence is the use of a problematic method. The problem-based learning method in high school is an educational and cognitive activity with the purpose of development and acquisition of knowledge and methods of activity within the situation of a problematic nature, introspection of situations, solving of formulated problems by proposing hypotheses, propositions, discussing, proving and testing of the correctness of these hypotheses.

The problem-based learning method involves an active search activity when a student has to activate previously learned material. This method is aimed at the development of skills of future specialists, the formation of professional-oriented thinking. The problematic method is based on the communicative approach (communicative situations of problem communication, role playing situations, discussion of problems, etc.). Particular attention is paid to practical classes as a form of educational process, the activation of which is achieved by updating, for example, role-playing situations that are close to professional and used for free communication in a situation that may arise in real conditions of professional activity, take the right position, adapt to their role and to test professional competence [7].

Playing games as an active method of imitation learning encourages all students in the group to communicate and use the learning communicative material. Creating a game gives the communicative learning a reflexive, and therefore more effective, character.

With regard to communicative competence, it is largely defined as the ability to communicate with others, as well as the set of knowledge, skills and abilities that help to establish and maintain these contacts, to penetrate deeply into the essence of information provided by the interlocutor [2].

Conclusions. The professional competence of future specialists is an integrative combination of qualities and skills, which contains such principal methods as the finding, obtaining, processing, presentation and the transmission of information. These methods also include the analysis, synthesis, comparison, generalization, systematization and the transformation of obtained information into knowledge. They are the most important qualities and skills of professional competence of future specialists.

One of the basic requirements of the modern labor market to a specialist is, first of all, an appropriate level of a future specialist's professional competence. Ukrainian scientists have determined that the most important task of modern education is its reorientation to the definition of professional competence. The professional competence determines the level of professionalism, and the achievement of required skills and abilities. It constitutes the purpose of professional activity of specialists.

The development of searching models of information focuses on the ability of students as seekers of information to understand, to reflect, to communicate professionally and to think critically, as the informative volume and new sources of information and its users are constantly increasing.

A special place in the process of student learning is the problem-based learning method, which helps to increase the efficiency and effectiveness of the educational process in higher education.

\section{References:}

1. The Great Interpretive Dictionary of Modern Ukrainian / Compiled and Editor-in-Chief V.T. Busel. Kyiv: Irpin: VTF "Perun", 2001. 1440 p. (in Ukrainian)

2. Balakhtar, V.V. Psychology and pedagogy: a textbook. Chernivtsi: Books-XXI, 2011. Pp. 70-71. (in Ukrainian)

3. Dichkivska, I. Formation of intellectual motives in the context of innovative training in the training of specialists: methodology, technology, theory, experience, problems. Collection of scientific works. Part 3. Kyiv - Vinnytsia, 2003. Pp. 327-331. (in Ukrainian)

4. Ziazun, I., \& Sagach, G. The beauty of pedagogical action: A manual for teachers, graduate students, students of secondary and higher education. Kyiv: Ukrainian-Finnish Institute of Management and Business, 1997. 302 p. (in Ukrainian)

5. Kirsanov, V. Technology Design Fields of Functional socio-cultural programs. Bulletin KNUKiM. "Pedagogy". 2002. № 6. (in Ukrainian)

6. Musys, N. Use pro spilni polityky Yevropeiskoho Soiuzu [All about common European Union policies]. Kyiv: "K.I.S.", 2005. (in Ukrainian)

7. Petrovskaia, L.A. Kompetentnost v obshchenyy. Sotsyalno-psykholohycheskyi trenynh: ucheb. posobye [Competence in communication. Socio-psychological training: studies. allowance]. Moskva: MHU, 1989. (in Russian)

8. Podlasyi, I., \& Tripolskaya, S. Formation of professional potential as a goal of teacher training. Native School. 1998. № 1, pp. 3-8. (in Russian)

9. Selevko, G. Modern educational technologies. Moskva, 1998. 255 p. (in Russian) 